\title{
EESTI SÕNAMOODUSTUS JA SÜNTAKS
}

\author{
REET KASIK
}

$\mathrm{V}$ aatlen artiklis sõnamoodustuse ja fraasimoodustuse seoseid. Selgemaid paralleele fraasimoodustuse ja sõnamoodustuse vahel on liitsõna struktuurides. Artiklis keskendun eeskätt tuletusele, aga eesti keeles moodustavad liitmine ja tuletamine mitmes mõttes kontiinumi, mistõttu arutlen mingil määral ka sünteetiliste liitsõnade teemal. ${ }^{1}$ Käsitlen eesti sõnamoodustuse ja süntaksi vahekorda kolmest aspektist. Esiteks vaatlen, kuidas süntaktilised printsiibid peegelduvad kompleksse sõna sisestruktuuris ehk käsitlen leksikaalse terviklikkuse ja fraasistruktuuri vahekorda. Teiseks vaatlen leksikaalset terviklikkust rikkuvaid süntaktilisi nähtusi sõnas ehk millise ulatusega võivad süntaktilised struktuurid olla inkorporeeritud sõnadesse. Kolmandaks jälgin, kuidas kompleksse sõna omadused peegelduvad nende süntaktilises käitumises, eriti argumendistruktuuris.

\section{Sissejuhatus}

Erinevad teoreetilised mudelid kasutavad olemuslikult erinevaid lähenemisi sõnastruktuuri ja fraasistruktuuri kõrvutamisel. Klassikalistes strukturaalsetes teooriates (nt Bloomfield 1933; Harris 1951) vaadeldi süntaksit üldiselt kui morfeemide ühendamist, ilma et oleks nähtud põhimõttelist vahet sõna ja fraasi vahel. Paljudes keeltes on teatud tüüpi süntaktilisi konstruktsioone, mis võivad produktiivselt esineda sõna sees, moodustades morfoloogilise konstruktsiooni. Eesti keeles näiteks võivad teatud ehitusega substantiivifraasid vabalt liituda üheks liitnimisõnaks (aknaraam, rahakott, koolimaja, keeleõpik; külmkapp, suurlinn, raskerock, loovintelligents). Morfeemide ühendamisega võib kaasneda kategooriamuutus: lillenimetus meelespea koosneb verbi pöördelisest vormist käskivas kõneviisis ja sellele eelnevast rektsioonilisest laiendist, adverb möödaminnes koosneb verbi gerundiivivormist ja sellele eelnevast partiklist. Sellised näited lubavad järeldada, et komplekssed sõnad võivad peegeldada keele süntaktilisi struktuure.

Ka transformatsioonigrammatika generatiivse semantika mudelis vaadeldakse sõnastruktuuri fraasi- või lausestruktuuri ühe alaliigina, mille järgi nii grammatiliste kategooriate moodustamine (Kayne 1994) kui ka sõnamoodustus (Hale, Keyser 1993) kuuluvad süntaksisse. Sellistes lähenemistes ei ole eraldi ruumi morfoloogilise komponendi jaoks ning seos sõnamoodustuse ja süntaksi vahel on triviaalne. Noam Chomsky eristas oma klassikaks saanud nominalisatsiooniartiklis (1970) ideosünkraatilisi nominalisatsioone (nagu rünnak) ja regulaarseid nominalisatsioone (nagu ründamine) põhjendusega,

${ }^{1}$ Liitsõnad jagunevad moodustusstruktuuri järgi sünteetilisteks liitsõnadeks ja tüviliitsõnadeks (vt Kasik 2013: 200). Sünteetilise liitsõna moodustusaluseks on süntaktiliselt seotud fraas ja liitsõna osade vahel on (morfo)süntaktiliselt motiveeritud laiendusseos (lasteaed). Tüviliitsõna osade vahel on üksnes leksikaalne seos (laudpõrand). 
et esimesed on formeeritud leksikonis, teised on formeeritud süntaksis. Generatiivse semantika mudelit on rakendatud ka eesti deverbaalsubstantiivide moodustusstruktuuri kirjeldamiseks (Kasik 1975).

Teised süntaksiteooriad, nagu põhjakeskne fraasistruktuurigrammatika (Pollard, Sag 1994) või leksikaalfunktsionaalne grammatika (Bresnan 2001), lähtuvad leksikaalse terviklikkuse põhimõttest, mille järgi süntaktilised reeglid või põhimõtted ei laiene sõna sisestruktuurile ega või moodustada sõnu.

Seisukoha, et komplekssetel sõnadel on tegelikult sama süntaktiline struktuur kui fraasidel, esitas generatiivses grammatikas esimesena Jindrich Toman (1983), tuues kasutusse sõnasüntaksi mõiste, ja seda on edasi arendanud paljud autorid: Elizabeth Selkirk (1982), Anna-Maria Di Sciullo ja Edwin Williams (1987), Rochelle Lieber (1992). Sõnasüntaksi keskne põhimõte on, et kompleksne sõna on süntaktilise sisestruktuuriga konstruktsioon, st sõna nagu fraaski on põhjakeskne struktuur. Derivatsiooniprotsessis on põhjaks afiks, mis realiseerib derivatsiooni ja vastutab derivatsiooniga kaasneva kategooriamuutuse eest. Põhjakesksus on vaieldav nii muutemorfoloogias kui ka tuletuses ja selle üle on palju diskuteeritud. Üks vaidlusaluseid ilminguid on nn relatiivne põhi (Selkirk 1982), ehk põhjana võivad eri alussõnadega varieeruda eri afiksid (minek, häving, teke). Lieber (1983) on osutanud, et sõnamoodustuses on põhjakeskse struktuuri põhimõttele väga raske allutada näiteks prefikseid, sest prefiksid enamasti ei determineeri tuletise leksikaalset kategooriat, sama prefiks võib seostuda eri sõnaliigi sõnadega (ebajumal, ebakindel, ebaõnnestuma). Eesti keeles on sõnasüntaksi põhimõtteid rakendatud lisaks deverbaalnoomenitele ka verbimoodustuse kirjeldamisel (vt Kasik 2010: 37-39).

Radikaalse süntaktilise lähenemise vastukaaluks on seisukoht, et süntaktilised reeglid või põhimõtted ei ole rakendatavad tuletiste või sõnavormide struktuuri kirjeldamisel. See tähendab, et sõnastruktuur on kirjeldatav morfoloogiliselt, mitte aga süntaktiliselt, sest sõna- või vormimoodustus juhindub põhimõtetest, mis on osaliselt või täiesti erinevad süntaksi põhimõtetest (Anderson 1992). Keskseid selle seisukoha lähtekohti on leksikaalne terviklikkus. Ka kompleksse struktuuriga sõna on leksikaalselt terviklik sõna, ja sõna kategooria erineb ühelt poolt morfeemi, teiselt poolt fraasi kategooriast, isegi kui piirid nende vahel on mõnikord raskesti kirjeldatavad. Kui sõnastruktuuri kirjeldada osade sõltuvusseoste kaudu, siis tuleb anda nendele struktuuridele niisugune tõlgendus, mis seletaks nende erinevust vastavatest süntaktilistest struktuuridest (vrd laste raamat ja lasteraamat). Eesti sõnamoodustuse uurijatest on leksikaalse terviklikkuse primaarsust rõhutanud eriti Krista Kerge (1996, 1998, 2001), praktiliselt lähtub sellest põhimõttest ka Silvi Vare (vt 1993).

\section{Leksikaalne terviklikkus ja süntaks}

Kokkuvõtliku ülevaate sellest, kuidas eri tüüpi süntaksimudelid käsitlevad sõnamoodustust, samuti teoreetilistest diskussioonidest sõnamoodustuse ja süntaksi seoste teemal on esitanud Andrew Spencer (2005). Siinses artiklis vaatlen sõnamoodustuse ja süntaksi seoseid eeskätt empiiriliselt eesti sõnamoodustustüüpide kontekstis. Leksikaalse terviklikkuse põhimõtet tuleb 
aktsepteerida ka sõnasüntaktilise lähenemise korral, kuivõrd sõnastruktuuri omadused erinevad fraasisüntaksis toimuvatest protsessidest. Kõige „süntaktilisemad" komplekssete sõnade hulgas on nominalisatsioonid ja sünteetilised liitsõnad. Chomsky regulaarsete nominalisatsioonide tõlgendusest (1970) järeldub, et sellised väljendid nagu vaenlase ründamine on tuletatud mine-liitega verbifraasist vaenlast ründama. Sellele seisukohale võib esitada nii poolt- kui ka vastuargumente. Ühelt poolt - kuna vaenlase ründamine võib eesti keeles tegelikult tähendada nii seda, et vaenlast rünnatakse, kui ka seda, et vaenlane ründab, siis see sunnib intuitiivselt järeldama, et mine-liide nominaliseerib pigem siiski konkreetset verbi, mitte fraasi, sest noomenifraasi struktuuri põhjal pole võimalik otsustada, missugust verbifraasi on nominaliseeritud. Teisest küljest osutavad aga sellised nominalisatsioonid nagu riigitaaste, riigihange, metsarüüste, meresaaste, kasutuselevõtt, rahvapett, pahakspanu, esiletõst just verbifraasi nominaliseerimisele, sest üksiksõnana, ainult verbist moodustatuna selliseid tuletisi eesti keeles praktiliselt ei kasutata - taaste, rüüste, saaste, võtt, pett, panu, tõst on küll ÕS-is olemas, aga keelekorpustest nende iseseisva, süntaktilise laiendita kasutamise kohta näiteid ei leia (vt ka Vare 2008).

Paljud sõnastruktuuri omadused on seletatavad leksikaalse terviklikkusega, kuigi mõned neist on kõnekamad kui teised. Teatud süntaktilised transformatsioonid, nagu infostruktuuri määravad elementide järjekorra muutused, topikalisatsiooni ja fokuseerimisega seotud ümberpaigutused, varieerumine, kommunikatiivsete lausetüüpidega kaasnevad siirded jne, ei või mõjutada sõnaosi (Spencer 2005: 78-79). Sõnaosade järjekorda ei saa muuta. Ka sünteetilised liitnimisõnad, kõige fraasilähedasem eesti keele sõnatüüpidest, on selliste protsesside suhtes immuunsed, vrd tulen koju, millal sa koju tuled, aga kojutulek - *tulekkoju ei ole sõnana võimalik.

Siiski on sõnastruktuuri ja lausestruktuuri vahel üleminekupiirkond, mis teeb sellest teatud mõttes kontiinumi - on nimelt analüütilisi konstruktsioone, mis kujutavad endast leksikaalseid üksusi, aga koosnevad rohkem kui ühest sõnast, näiteks väljendverbid ja ühendverbid, mille osade järjekord võib vahelduda ja osad võivad olla süntaktiliselt üksteisest lahus: tähele panema, paneb tähele, pane nü̈̈d hästi tähele. Sellistelgi konstruktsioonidel on süntaktilisi piiranguid. Partikkel võib olla enne või pärast objekti (loe läbi see raamat, loe see raamat läbi), aga konstruktsioonides, kus partikkel eelneb verbile (ära minnes, läbi loetud), ei saa partiklit ja verbi lahutada (*ära kiirustades minnes, *läbi raamat loetud, *osa koosolekust võtma). Teatud konstruktsioonides võib infinitiivide sõnajärg siiski muutuda (peab panema tähele, koosolekust pidi võtma osa ka president). Sünteetilistes liitsõnades sellised ümberpaigutused võimalikud ei ole (osavõtt, äraminek, läbilugemine). Selle taustal võime näha, et partikli-verbi konstruktsioonidel on mõningaid omadusi, mille poolest nad sarnanevad süntaktiliste struktuuridega, ja teisi omadusi, mille poolest need sarnanevad morfoloogiliste struktuuridega. Sellegipoolest on tegemist ühe leksikaalse üksusega, süntaktilised reeglid ei või muuta selliste ühendite tähendust. Sageli on sellistel konstruktsioonidel idiosünkraatiline tähendus, nad kuuluvad idioomide suurde rühma. Need on konstruktsioonilised idioomid, kus süntaksisse lisanduvad semantilised struktuurid (vt Ackerman, LeSourd 1997; Jackendoff 2002). 


\section{Süntaktilised nähtused sõnas}

\subsection{Sõnaosade koordineerimine}

Ka leksikaalset terviklikkust aktsepteerides tuleb möönda, et sõnamoodustuses on leksikaalset terviklikkust rikkuvaid nähtusi, mis seostuvad süntaksiga. Üks sagedasemaid on sõnaosade koordineerimise võimalus. Liitsõnu rinnastades on tavaline, et neist võib ära jätta korduva tüveosa: õuna-ja marjaaed, puu-või kivimaja, suur-ja väikeaktsionärid; kuuma-ja külmakartlik, kirsivõi lipupunane; eel-ja järelhindama, ala-või ülekoormama.

Selline korduva sõnaosa väljajätt on võimalik üksnes siis, kui laiendsõnad on mingi ülemmõiste kaudu semantiliselt seotud, nii et nende vahel on mingi intuitiivses mõttes „loomulik rinnastus” ja neil on põhja suhtes sarnane süntaktiline funktsioon. Kui sõnaosade süntaktiline seos oma põhjaga on erinev, siis selliste sõnaosade vahel pole nn loomulikku rinnastust ja korduvat tüveosa ära jätta ei saa: *kooli-ja kivimaja, *hapu-ja kohvikoor. Ka leksikaliseerunud tähendusega liitsõnades, kus semantika ei toetu sõnaosadevahelisele süntaktilisele funktsioonile, ei saa korduvat tüveosa välja jätta: *raamatu-ja orjapidaja, *aja- ja paberileht.

Kui laiendosade vahel on semantiline seos, pole takistusi ka iseseisva lekseemina mitteesinevate kinnistüvede koordinatsiooniks: liht-ja liitlause, argija pühapäev.

(1) Tüüpiline pilt kevadisest Tallinnast, kus jalakäijad lõhuvad end kõnni- ja autod sõiduteedel. (PM 3. IV 2013) ${ }^{2}$

(2) Pärast jaanipäeva jäävad ära teisi- ja kolmapäevased lennud. (PM 3. IV 2013)

Mingis ulatuses võib selline rinnastus laieneda ka prefiksitele: pre- ja postpositsioonid; homo-ja heteroseksuaalne. See puudutab prefiksipaare, mis vastanduvad teineteisele semantiliselt niiviisi, et võimaldavad loomulikku koordinatsiooni. Eesti prefiksite hulgas selliseid paare ei ole, seepärast saab prefiksite koordinatsioonivõimalusi arutleda üksnes prefiksiliste võõrsõnade näitel. Küll aga võib prefiks $e b a$ - koordineeruda partikliga:

(3) Klassitsistlik maitse taunis igasugust eba- ja üleloomulikkust. (G)

Sarnasele süntaktilisele seosele viitab ka see, et sõnaosa võib koordineeruda süntaktilise laiendiga:

(4) Poliitikute (eks- ja praegune peaminister) sõnavõttudest koorus teadlastele soodne vastupakkumine. (AK)

Kõik need näited puudutavad kompleksse sõna laiendosade koordinatsiooni. Reeglina eeldab selline koordinatsioonivõimalus, et rindfraasi väljajäetav põhi on lekseem. Näiteks ei saa teineteisele vastanduvaid prefikseid koordi-

\footnotetext{
${ }^{2}$ Näitelaused on tähistatud järgmiselt. Eesti kirjakeele korpusest (www.keeleveeb.ee/ korpused) võetud näitelausetele on lisatud viide allkorpusele: AK - ajakirjanduskorpus, IK - ilukirjanduskorpus. Viitega G tähistatud laused on leitud otsinguga www.google.ee. Muud tähistused: PM - Postimees, KK - Keel ja Kirjandus. Viiteta näitelaused on autori koostatud.
} 
neerida, kui kompleksse sõna põhjaks on sõnaosa: *eks- ja import, *süno- ja antonüümid. Päris võimatu see siiski ei ole:

(5) Praegusel juhul on siinne vestlus pigem mono- kui dialoog. (G)

Eesti sõnamoodustuses haakub selle rühmaga kond-liiteliste sõnade koordinatsioon. Kasutatavaim näide on mees- ja naiskonnad, aga kond-liite väljajätt on avaram, kuigi mitte eriti produktiivne: näited on harvad, näiteks leidsin guugeldades vaid ühe kasutusjuhu maa-ja kihelkonnad, aga 430 esinemust fraasile maakonnad ja kihelkonnad.

(6) Kuidas oma programmile võita juurde vaatajas- või kuulajaskonda. (G)

(7) Mentoraasta poole peal muutus firma juht- ja töötajaskond ning omanikestruktuur. (G)

(8) Ürgselt seostas üksikinimest tihedalt pere- ja sugukond. (G)

(9) Siin on Eesti maa- ja kihelkonnad oma vanasõnafondidega. (G)

Teiste sufiksite väljajätt rinnastatud ühendites võimalik ei ole: *isa- ja ematu, *naise-ja mehelik, *ruudu-ja triibuline. Saab küll öelda Meie kelder on nü̈̈d täiesti roti- ja hiirevaba, mitte aga *Meie kelder on nü̈̈d täiesti roti-ja hiiretu.

Komplekssete sõnade korduva laiendosa väljajätt on harvem, kuigi fraasis on see tavaline: meie kooli opilased ja õpetajad. Liitsõnadeski on see põhimõtteliselt võimalik (keelehooldajad ja -korraldajad), aga tundub, et ühine laiendosa ei ole enamasti piisav komplekssete sõnade rinnastusseose kandja: ?laudpõrand ja -lagi, ?vanaisa ja -ema, ?pildiraamat ja -album. Kui sünteetilise liitsõna ja fraasi tähenduserinevus on väike (vrd merepõhi ja mere põhi), on rindühendites loomulikum lahkukirjutamine: keele hooldajad ja korraldajad, sõja pooldajad ja vastased, päikese tõus ja loojang. Korduva prefiksi väljajätt on küsitav: *ebaloomulik ja -inimlik. Olen siiski leidnud ajakirjandusest vähemalt ühe vastava näite:

(10) Mida uuemas mõistesüsteemis nimetatakse transtekstuaalseteks või -meedialisteks seosteks. (KK 2013, nr 3)

Kuigi eesti keeles on ka sufiksipaare, mis vastanduvad teineteisele semantiliselt niiviisi, et võimaldavad loomulikku koordinatsiooni, ei ole korduva tuletustüve väljajätt võimalik: *õnnelik ja -tu, *arukas ja -tu. See toetab tuletiste leksikaalset terviklikkust ja räägib tugevasti vastu sufiksite käsitamisele analoogiliselt süntaktilise fraasi põhjaga ja tuletiste sisestruktuuri käsitamisele põhjakeskse süntaktilise struktuurina.

Selle probleemi tõsisemat uurimist raskendavad kaks asjaolu. Esiteks, on raske otsustada, kas selliseid elemente nagu pre-, post- ja eks- või eba-ja -kond tajutakse afiksite või liitsõnaosadena. Näiteks vaatajas-ja kuulajaskonna kõrval võib näha ka liitsõnasarnast rinnastust:

(11) Ansambel loodab, et „Silmad vees” leiab samuti oma vaataja- või kuulajaskonna. $(\mathrm{G})$ 
Teiseks, koordinatsiooni semantika ja süntaks ei ole kaugeltki selged. Eesti keeles on olemas ka nn rühmafleksioon või siirdatud afiksatsioon (ema ja isata, koore ja suhkruga, lume või vihmana, jõe või järveni). Selline korduva käändelõpu väljajätt rinnastatud ühenditest viitab kontiinumile teatud käändelõppude ja postpositsioonide vahel (vrd metsa ja mere taga, lume või vihma käes), aga selline rinnastusvõimalus ei laiene tuletistele, välja arvatud kond-liitelised sõnad. On siiski üks mõeldav arengusuund. Sõnamoodustuses on väga tugev roll analoogial ja sõnamallidel. On näiteks märgata, et omadussõnaliide -tu on hakanud käituma mõnes mõttes analoogiliselt ilmaütleva käände lõpuga -ta. Nii on -tu ainus liide, mis käändelõpu analoogial võimaldab vastandada ainsuslikku ja mitmuslikku tüve ja võib morfoloogiliselt liituda de-mitmuse tunnusele: internetitekstides leiduvad kätetu, lastetu, sõpradetu, juurtetu, soovidetu, asjadetu. Kuna ilmaütleva käände lõpu võib rinnastatud fraasis kordamata jätta, siis pole võimatu, et see laieneb kunagi ka tu-tuletistele. Igatahes võib arvata, et kui, siis ema ja isatu laps, kassi ja koeratu pere jts tulevad kasutusele enne kui ruudu või jooneline vihik, naise või mehelik veetlus jms. Seni pole õnnestunud selliseid kasutusnäiteid siiski leida. ${ }^{3}$ Veel on üks asjaolu, mis võib mõjutada sõnaosade väljajättu. Ei ole selge, kas ja kuivõrd sõltub koordinatsioonivõimalus konjunktsioonist ja kontekstist: enamik kasutusnäiteid on ühesilbilise (ja, või) konjunktsiooniga, aga kas oleks võimalik ka ?mees-, aga hoopis harvem naiskonnad, ?vaatajas-, järelikult ka kuulajaskond; ?Tartu pani välja ainult mees-, aga Tallinn ka naiskonnad.

\subsection{Liitsõnatuletus}

Teine süntaksiga põimuv tuletusmall on selline, kus sufiks liitub fraasile. Liitsõnaks võivad eesti keeles produktiivselt liituda mitmesuguse struktuuriga noomenifraasid, aga üsna suures ulatuses alluvad nad ka tuletusele, nii et süntaktiline seos ilmneb tuletustüves ja tuletusliide käitub fraasipõhjana. Nähtus nimega liitsõnatuletus, kus süntaktilisest fraasist moodustub liite abil uus lekseem, mis on siis struktuuri järgi samaaegselt nii liitsõna kui tuletis, on eesti keeles produktiivne kahes tuletuspiirkonnas. Liitsõnatuletust esineb regulaarselt adjektiivituletuses ja deverbaalses noomenituletuses. Liitsõnatuletiste ja liitsõnade piir on kontiinumilaadne. Kui tuletis on kasutatav ka laiendita, võib sõna sisestruktuuri analüüsida kaheti: liitsõnana või fraasist moodustatud tuletisena: pesa+ehitaja või pesa ehitama $>$ pesaehita-ja. Kindlad liitsõnatuletised on sellised, mille fraasipõhjast moodustatud tuletis iseseisva lekseemina, st laiendita ei esine: kahekorruseline, metsatagune, kuupaiste, pahakspanu, tähelepanelik (vrd *korruseline, *tagune, *paiste, *panu, *panelik). Liitsõnatuletised sarnanevad oma süntaktiliste omaduste poolest liitsõnadega. Neist moodustatud rindfraasides võib ära jätta korduva tüveosa ( $m a a-j a$ meretagune, kahe- või kolmetoaline), samuti on liitsõnatuletus, nagu üldse liitsõnamoodustus, osati mõjutatud kehtivatest ortograafiareeglitest, mis määravad sõnade kokku- ja lahkukirjutamist, vrd kahekorruseline ja kolmekümne kahe korruseline, metsatagune ja paksu metsa tagune, kuupaiste ja täiskuu paiste.

\footnotetext{
${ }^{3}$ Korpustes ei leidu või ei ole võimalik otsida kõiki juhumoodustisi või harva kasutatavaid keelendeid, mistõttu mingi moodustustüübi ebaproduktiivsust (neologismide puudumist) on raskem osutada kui produktiivsust.
} 
Liitsõnatuletus eesti keeles ei sõltu niivõrd kindlast sufiksist, vaid sõnamoodustuse ulatuse määrab tuletuse aluseks oleva fraasi struktuur, mida võib substantiveerida või adjektiveerida erinevate liidetega. Deverbaalne liitsõnatuletus põhineb verbi argumendistruktuuril ja selle inkorporeerimist sõnatuletusse vaatlen artikli neljandas osas. Siin kirjeldan lühidalt adjektiivide moodustuse aluseks olevaid fraasitüüpe. Fraasil põhinevaid adjektiive moodustatakse kõigi produktiivsete adjektiiviliidetega. ne-liiteliste adjektiivide moodustus on produktiivne adpositsioonifraasidest (stardieelne, sünnipuhune, õhinapõhine, suukaudne, riigiülene), võrdlusstruktuuriga adjektiivifraasidest (päevapikkune, puukõrgune, jõelaiune, terasetugevune), adjektiivlaiendiga substantiivifraasidest (mahedahäälne, ausameelne, õigeaegne, hallisilmne) või kvantorfraasidest (nelinurkne, kolmekordne, mitmekülgne). line-liiteliste adjektiivide moodustus on avatud adjektiivlaiendiga substantiivifraasi ja kvantorfraasi alusel (nõrganärviline, madalalaubaline, neljaköiteline, paljurahvuseline). Adpositsioonifraasist harilikult line-tuletisi ei moodustata, v.a prepositsiooniga üle (üleriigiline, üleeuroopaline) ja kinnistüvega ala (vrd alla): alamõoduline, üle- ja alakaalulised. Substantiivifraasist ja kvantorfraasist moodustatakse adjektiive ka lik-liitega (laiaulatuslik, täisväärtuslik, heasüdamlik, paljutähenduslik, kolmevaatuslik), samuti võib lik-tuletuse aluseks olla verbifraas (külmakartlik, meeleheitlik, kohusetäitlik, ettenägelik, vastutulelik) või mitmeosaline nimi (juhanliivilik, jürgenroostelik). Verbifraasist saab tuletisi matu-liitega (ennekuulmatu, jumalakartmatu). Olen leidnud ilukirjandusest ühe liitsõnatuletise ka jas-liitega:

(12) Avastate, et teie käed on täis kilekotikesi andaluusia roisulõhnjate oliividega. (IK)

\subsection{Fraas liitsõna osana}

Leksikaalse terviklikkuse põimumist süntaksiga võib leida ka siis, kui seotud fraas saab liitsõna osaks (hullulehmatõbi, soolaleivapidu, hallipassimees, kaheinimesevoodi, neljakuningapäev, kolmevärvitrükk), aga erinevalt liitsõnatuletusest ei ole selline liitsõnamoodustus regulaarne. Et fraas võiks saada liitsõna osaks, peab see olema mingil viisil mõistena fikseerunud või leksikaliseerunud (mingis ebamäärases intuitiivses mõttes). Kuigi esmapilgul on sellistes liitsõnades nagu kaheinimesevoodi, kuumaveekraan jts raske näha laiendfraasi mingi eristuva mõistena, on siiski ilmne, et igasugused substantiivi- või kvantorfraasid liitsõna osaks ei saa, vrd suure linna elanik, ausa mehe maine, kuue tänava ristmik, kümne hektari talu.

Huvitava rühma moodustavad tekstisidusad ad hoc liitsõnad, mille laiendosaks võib olla suvalise struktuuriga süntaktiline fraas: vali-mind-naeratus, mitte-minu-tagaõue-hoiak, keelan-käsin-stiil:

(13) Tõeline kord-saja-aasta-kestel-üleujutus tekitas Shanghais tõsiseid kahjustusi. (AK)

(14) Massilist minu-laps-sinu-korterisse-petuskeemi seoses koolivalikuga pole täheldatud, kirjutas Kiisler. (AK)

Mõni selline ühend võib ka leksikaliseeruda, nagu tõlkelaenuline äraunustamind-lill. On mõeldav, et sellised fraasid, kui nad on piisava leksikaalse seotusega ja viimane koostisosa on tuletustüvele sobiva fonoloogilise kujuga, 
võiksid alluda ka tuletusele, näiteks ?mitteminutagaõuelik hoiak või ?Mitteminutagaõuelised nõudsid otsuse ülevaatamist. Korpustest pole selliseid tuletisi õnnestunud leida, aga tundub, et emakeelekõneleja keelevaistuga need otseses vastuolus ei oleks.

\section{Argumendistruktuuri realiseerimine}

\subsection{Predikaatnominalisatsioonid}

Kolmandaks vaatlen argumendistruktuuri realiseerimist tuletuses. Chomsky nominalisatsioonikäsitlusest (1970) on tuttav predikaatnominalisatsioonide (teonimede) käsitlus süntaktilise afiksatsioonina (vt ka EKG II 1993: 269270). Teonimed on sõnad, mis on tuletatud verbist, aga millel on noomenite morfoloogilisi ja süntaktilisi tunnuseid. Lingvistiliselt on deverbaalnoomenitega seotud kaks põhimõtteliselt erinevat aspekti. Ühelt poolt on deverbaalid kaotanud osa verbi morfosüntaktilistest omadustest, teiselt poolt on nad juurde saanud teatud noomeniomadusi. Üks säilinud verbitunnuseid on verbi semantika, nimelt argumendistruktuur või valents. Deverbaalnoomen seob endaga regulaarselt laiendeid, mis vastavad alusverbi argumentidele. Kõige rohkem on räägitud alusverbi subjekti ja objektina esinevate argumentide edasiandmisest noomeni laiendina, kusjuures need laiendid on morfosüntaktiliselt saanud noomenilaiendi vormi:

(15) jahimehed kütivad põtru põtrade küttimine (jahimeeste poolt)

jahimeeste põdraküttimine

jahimeeste küttimine

Põhimõtteliselt võib genitiivtäiend eesti keeles väljendada nii tegijat kui ka tegevusobjekti, aga mitte mõlemaid samas fraasis (*jahimeeste põtrade küttimine), välja arvatud juhul, kui objektiline genitiiv on liitunud deverbaaliga liitsõnaks (jahimeeste põdraküttimine, kokkade toiduvalmistamine). Intransitiivsete verbide nominaliseerimisel on genitiivtäiend alati subjektiline (poiste kaklemine, üliõpilaste kogunemine, õpetaja suhtumine), transitiivsete verbide tuletiste laiendina aga harilikult objektiline (maja ehitamine, maksude kogumine, naabri tervitamine).

Kui objektlaiendit ei ole, on sobiva konteksti korral ka transitiivsete verbidega võimalik seostada subjektilist genitiivtäiendit:

(16) Faktide teadmisest üksi jääb väheks. (AK)

(17) Et euro-eurooplased pole harjunud hundiga külg külje kõrval elama, toitub nende teadmine selle kiskja kohta rahvakeelest. (AK)

(18) Sissetuleku suurus horoskoobi uskumist ei mõjuta. (AK)

(19) Minu uskumist pidi on jõulud rahu ja kodu aeg. (AK)

Üldine nominalisatsiooni morfoloogiline tunnus on mine-liide, selle kõrval võib osast verbidest tuletada noomeneid ka teiste liidetega. Teiste liidetega moodustatud protsessituletiste olemasolu (tulek, häving, kirjeldus, tõrje) ei takista mine-nominalisatsiooni ja nii subjekt- kui objektgenitiiv võib laiendada 
ka teiste liidetega tuletatud protsessituletisi (riigi häving, kaaslaste tulek, olukorra kirjeldus, keemikute sääsetõrje).

(20) Mõeldud on see kahjurite tõrjeks avamaal ja katmikalal. (AK)

(21) Tugeva välisvindiga värava poole lennanud palli imes sisse Roberto, kelle tõrje ebaõnnestus täielikult. (G)

Alusverbi muud rektsioonilised laiendid säilitavad ka noomenilaienditena oma vormi: hommikust õhtuni täie jõuga töötamine, ministeeriumist ülikoolile vajalike vahendite tellimine. Uurimist väärib adverbi ja adjektiivi vahekord. Harilikult saab verbi laiendav adverb nominalisatsioonis noomenilaiendile iseloomuliku adjektiivivormi: Poiss jooksis kiiresti > poisi kiire jooks (*kiirestijooks).

Tundub, et mine-tuletise laiendina pole võimatu ka adverb, eriti järeltäiendina:

(22) Ministeerium reageeris kiiresti ja sõbralikult.

(23) Ministeeriumi kiire ja sõbralik reageerimine üllatas meid.

(24) ? Ministeeriumi kiiresti ja sõbralikult reageerimine üllatas meid.

(25) Meid üllatas ministeeriumi reageerimine nii kiiresti ja sõbralikult.

\subsection{Argumentnominalisatsioonid}

Teist tüüpi nominalisatsioonidest on produktiivne ja- ja $n u$-liiteliste tegijanimede moodustamine, mille referendiks on alusverbi subjektargument (korraldaja, ehitaja, ärganu, lugenu). Ka objektargument on süntaktiliselt aktiivne ning võtab ja-tuletise laiendina genitiivtäiendi vormi (ürituse korraldaja, tänavate ehitaja), nu-tuletise laiendina aga säilitab objekti vormi (matemaatikat oppinu, luuletuse kirjutanu). Osa tuletisi seostub ka muude verbilaienditega: rongiga saabuja, kahel käel mängija, kevadel kooli lõpetanu, armees teeninu.

Erinevalt predikaatnominalisatsioonist on verbisüntaksi võimalused argumentnominalisatsioonis piiratumad, vrd:

(26a) Ürituse korraldamine Tallinnas sajale osavõtjale kahe nädala pärast. (26b) *Ürituse korraldaja Tallinnas sajale osavõtjale kahe nädala pärast.

Teised argumentnominalisatsiooni sufiksid ei luba harilikult verbi objekti või muude laiendite väljendamist (vrd lugema õppija, aga *lugema õppur), kuid mingis ulatuses on seegi võimalik (maja omanik, saali valvur).

Transitiivsetest verbidest saab moodustada ka tuletisi, mille referendiks on verbi objektargument: oodatu, armastatu, korraldatu. Selliste tuletistega on võimalik seostada nii lähtelause subjekti kui ka muid verbilaiendeid: minu tehtu, kemikaalidega töödeldu, möödujate poolt kunstliku hingamisega ellu äratatu, eile ühiselt alustatu.

\subsection{Sünteetilised liitsõnad ja noomeni inkorporeerimine}

Eesti keeles ei ole fraasi ja liitsõna piir kuigi range. Nii võivad ka deverbaal ja selle laiend liituda sünteetiliseks liitnimisõnaks, mille põhiosa on substantiiv, laiendosa näib aga süntaktiliselt sõltuvat verbist, tähistades selle subjekti 
(27a), objekti (27b) või muud sõltuvat laiendit (27c). See inkorporeeritud laiendite võimalus on süntaktilise sõnamoodustuse klassikaline juhtum. Selline laiend on eriti tavaline protsessi väljendavates liitsõnades:

(27a) lumesadu, tuuletõmbus, lapsenutt, palgatõus, päikeseloojang, kuupaiste;

(27b) kalapüük, rahapesu, viljalõikus, piletimüük, enesekaitse, toiduvalmistamine;

(27c) ellusuhtumine, ämbrisseastumine, paigaltnihkumine, maalesõit, peastarvutus.

Kuigi nii subjekt- kui objektgenitiiv võib liituda oma põhjaga liitsõnaks, on siin üks piirang: subjektgenitiiv harilikult mine-tuletisega liitsõna ei moodusta (lapse nutmine, palga tõusmine, päikese loojumine), objektgenitiiv võib aga moodustada liitsõna nii mine-tuletisega kui muude protsessituletistega.

Deverbaalne liitsõnamoodustus võib hõlmata ka tegijanimesid ning passiivkonstruktsioone: toiduvalmistaja, majaostja, töölesõitja, söekaevur, keelehooldur, vettesünnitanu, elluäratatu, käsitsitehtu. Deverbaalsed adjektiivid võivad laiendosana inkorporeerida alusverbi objekti, mis liitadjektiivi laiendosana on genitiivikujuline: hinnatundlik, energiasäästlik, asjatundmatu, jumalakartmatu.

Selline inkorporeeritud verbilaienditega liitsõnamoodustus on produktiivne eesti noomenimoodustuses, aga laieneb mingil määral ka liitverbidele: taaskäivitama, kiirparandama, ravikindlustama, tiivaripsutama. Genitiivne või lühitüveline laiendosa viitab selgelt, et selline verb on edasimoodustus liitnoomenist (vrd taaskäivitamine, kiirparandus, ravikindlustus, tiivaripsutamine), ilma nimisõnalise vaheastmeta verb otse oma laiendeid sõnastruktuuri ei inkorporeeri (*ma majaostan, *ma kojulähen). ${ }^{4}$ Küll aga võib verbi partitsiibivorm analoogiliselt deverbaalsete tuletistega inkorporeerida verbilaiendi ja kategoriseeruda liitadjektiiviks (hästikasvatatud laps, teedrajav saavutus).

\section{Kokkuvõte}

Süntaksil on oluline roll sõnamoodustuse uurimisel. On kaks teoreetilist võimalust tõlgendada artiklis kirjeldatud konstruktsioone. Üks on leksikaalne, teine radikaalselt süntaktiline seletus. Leksikaalse seletuse järgi on tuletis moodustatud morfoloogiliselt, aga ta võib „pärida” alussõna teatud süntaktilisi omadusi, nagu argumendistruktuuri realiseerimine. Radikaalse süntaktilise lähenemise järgi leiab sõnamoodustus aset süntaksis ja tuletusliited on nagu sõnadki süntaktilise tasandi lähteüksused. Mõned teoreetilised süntaksimudelid on üles ehitatud nii, et hõlmavad suure osa või kogu sõnamoodustuse kui süntaksi erijuhu. Teised sõnasüntaktilise lähenemise järgijad näevad sõnades moodustusstruktuuri, mis mingis ulatuses sarnaneb fraasistruktuuriga. Teiste sõnadega: mõned süntaktilist sõnamoodustust pooldavad teoreetikud otsivad kogu sõnamoodustuse kirjeldusele sobivat süntaktilist lähenemist, teised näivad arvavat, et süntaksiga seostuvad vaid mõned sõnamoodustuse aspektid. Kõige „süntaktilisemad” konstruktsioonid on nominalisatsioonid

${ }^{4}$ Eesti liitverbide pöördmoodustuse kohta liitsubstantiivist vt Vare 2003 ja Kasik 2013: 234-241. 
ja sünteetilised liitsõnad, eesti keeles on produktiivne ka fraasil põhinev liitsõnatuletus. Täies ulatuses süntaktilise sõnamoodustuse teooriale leidub väga vähe toetavaid argumente. Siiski on selge, et on olulisi aspekte, milles süntaks põimub sõnamoodustusega, ükskõik missugust teoreetilist lähenemist ka silmas ei peetaks. Olulisimatena neist nähtustest on siin eesti keele baasil kirjeldatud sõnaosade rinnastust, fraasil põhinevat sõnamoodustust ja verbi argumendistruktuuride realiseerimist deverbaalses noomenimoodustuses.

\section{Kirjandus}

A c k e r m a n, Farrell, Le S o u r d, Philip 1997. Toward a lexical interpretation of phrasal predicates. - Complex Predicates. Toim A. Alsina, J. Bresnan, P. Sells. Stanford University: Center for the Study of Language and Information, lk 67-106.

Anderson, Stephen 1992. A-Morphous Morphology. Cambridge: Cambridge University Press.

B l o o m fi e ld, Leonard 1933. Language. New York: Holt.

B r e s n a n, Joan 2001. Lexical Functional Syntaks. Oxford: Blackwell Publishers. Chomsky, Noam 1970. Remarks on nominalizations. - Reading in English Transformational Grammar. Toim R. Jacobs, R. Rosenbaum. Waltham, MA: Blaisdell, lk 184-221.

Di S c i ull o, Anna-Maria, Willi a m s, Edwin 1987. On the Definition of Word. Cambridge, MA: MIT Press.

EKG II = Mati Erelt, Reet Kasik, Helle Metslang, Henno Rajandi, Kristiina Ross, Henn Saari, Kaja Tael, Silvi Vare, Eesti keele grammatika II. Süntaks. Lisa: Kiri. Tallinn: Eesti Teaduste Akadeemia Keele ja Kirjanduse Instituut, 1993.

H a le, Kenneth, Keyser, Jay 1993. On argument structure and the lexical expression of syntactic relations. - The View from Building 20: Essays in linguistics in honor of Sylvain Bromberger. Toim K. Hale, J. Keyser. Cambridge, MA: MIT Press, lk 53-110.

H a r r i s, Zellig 1951. Structural Linguistics. Chicago: University of Chicago Press. J a c k e n d off, Ray 2002. English particle constructions, the lexicon and the autonomy of syntax. - Verb Particle Explorations. Toim N. Dehe, R. Jackendoff, A. Macintyre, S. Urban. Berlin: Mouton de Gruyter, lk 67-94.

K a s i k, Reet 1975. Verbide ja verbaalsubstantiivide tuletusvahekorrad tänapäeva eesti keeles. (Keele modelleerimise probleeme 5.) Tartu.

K a s i k, Reet 2010. Eesti keele sõnatuletus. Kolmas, parandatud trükk. Tartu: Tartu Ülikooli Kirjastus.

Ka s i k, Reet 2013. Komplekssete sõnade struktuur. (Tartu Ülikooli eesti keele osakonna preprindid 3.) Tartu.

K a y $\mathrm{n}$ e, Richard 1994. The Antisymmetry of Syntax. Cambridge, MA: MIT Press.

Kerge, Krista 1996. The Estonian agent nouns: grammar versus lexicon. Sprachtypologie und Universalienforschung (STUF), kd 49, nr 3, lk 286-294.

K e r g e, Krista 1998. Vormimoodustus, sõnamoodustus, leksikon. Oleviku kesksõna võrdluse all. Tallinn: Tallinna Pedagoogikaülikooli Kirjastus.

K e r g e, Krista 2001. Action nouns on -mine in Estonian grammar and lexicon. Nordic and Baltic Morphology: Papers from a NorFA Course, Tartu, June 2000. (Studies in Languages 36.) Toim J. Niemi, J. Heikkinen. Joensuu: University of Joensuu, Faculty of Humanites, lk 34-45. 
L i e b e r, Rochelle 1983. Argument linking and compounds in English. - Linguistic Inquiry, kd 14, lk 251-286.

Lieber, Rochelle 1992. Deconstructing Morphology. Chicago: University of Chicago Press.

P o 1 l a r d, Carl, S a g, Ivan 1994. Head-Driven Phrase Structure Grammar. Chicago: Chicago University Press.

S e lk i r k, Elizabeth 1982. The Syntax of Words. Cambridge, MA: MIT Press.

S p e n c e r, Andrew 2005. Word-formation and syntax. - Handbook of Word-Formation. Toim P. Štekauer, R. Lieber. Dordrecht: Springer, lk 73-97.

To m a n, Jindrich 1983. Wortsyntax. Eine Diskussion ausgewählter Probleme deutscher Wortbildung. Tübingen: Niemeier Verlag.

V a r e, Silvi 1993. Tuletusliitest uue nurga alt. - Keel ja Kirjandus, nr 8, lk 530536.

V a r e, Silvi 2003. Back-formation of verbs in Estonian. - Languages in Development. Toim H. Metslang, M. Rannut. München: Lincom Europa, lk 123-132.

V a r e, Silvi 2008. Potentsiaalsetest sõnadest leksika ja grammatika vaatenurgast. - Keel ja Kirjandus, nr 7, lk 531-551.

\section{Estonian word formation and syntax}

Keywords: word formation, word syntax, synthetic compounds, lexical integrity, nominalization, Estonian language

The article analyses the relations between word formation and phrase formation. More or less clear parallels between the two have been found in compound structures. The main focus is derivation, but as Estonian compounding and derivation belong to the same continuum in more than one sense there is also some discussion of synthetic compounds. The relations of Estonian word formation and syntax are discussed from three aspects. First, it is studied how syntactic principles are reflected in word internal structure, i.e. what the relations are between lexical integrity and phrase structure. Second, a closer look is taken at such word syntactic phenomena that violate lexical integrity, in other words, it is examined to what extent syntactic structures can be incorporated in words. The phenomena under study are coordination of word parts, phrase-based derivation (=when an affix apparently attaches to a whole phrase) and phrase as a component of a compound word (=when entire phrases enter into compounds). Third, it is investigated how the properties of a complex word are reflected in its syntactic behaviour, especially in its argument structure.

Reet Kasik (b. 1946), PhD, Docent emeritus, senior researcher, University of Tartu, reet.kasik@ut.ee 